\title{
Comparison of cytotoxicity and genotoxicity of 4-hydroxytamoxifen in combination with Tualang honey in MCF-7 and MCF-10A cells
}

\author{
Nik Soriani Yaacob ${ }^{*}$ and Nur Faezah Ismail
}

\begin{abstract}
Background: The Malaysian Tualang honey $(\mathrm{TH})$ is not only cytotoxic to human breast cancer cell lines but it has recently been reported to promote the anticancer activity induced by tamoxifen in MCF-7 and MDA-MB-231 cells suggesting its potential as an adjuvant for the chemotherapeutic agent. However, tamoxifen produces adverse effects that could be due to its ability to induce cellular DNA damage. Therefore, the study is undertaken to determine the possible modulation of the activity of 4-hydroxytamoxifen (OHT), an active metabolite of tamoxifen, by $\mathrm{TH}$ in non-cancerous epithelial cell line, MCF-10A, in comparison with MCF-7 cells.

Methods: MCF-7 and MCF-10A cells were treated with TH, OHT or the combination of both and cytotoxicity and antiproliferative activity were determined using LDH and MTT assays, respectively. The effect on cellular DNA integrity was analysed by comet assay and the expression of DNA repair enzymes was determined by Western blotting.

Results: OHT exposure was cytotoxic to both cell lines whereas TH was cytotoxic to MCF-7 cells only. TH also significantly decreased the cytotoxic effect of OHT in MCF-10A but not in MCF-7 cells. TH induced proliferation of MCF10A cells but $\mathrm{OHT}$ caused growth inhibition that was abrogated by the concomitant treatment with $\mathrm{TH}$. While $\mathrm{TH}$ enhanced the OHT-induced DNA damage in the cancer cells, it dampened the genotoxic effect of OHT in the non-cancerous cells. This was supported by the increased expression of DNA repair proteins, Ku70 and Ku80, in MCF-10A cells by TH.
\end{abstract}

Conclusion: The findings indicate that TH could afford protection of non-cancerous cells from the toxic effects of tamoxifen by increasing the efficiency of DNA repair mechanism in these cells.

Keywords: Tualang honey, Tamoxifen, MCF-10A, MCF-7, Cytotoxicity, DNA damage, DNA repair enzymes

\section{Background}

Chemotherapeutic agents effectively kill most of the cancer cells. However, cellular specificity of those drugs remains a major obstacle where side effects often develop as a result of the drugs' action on the normal cells and tissues. Tamoxifen is commonly used to treat breast tumors that are classified as estrogen receptor positive $(E R+)$ since the 1980s [1,2]. It blocks the estrogenic effects responsible for growth and proliferation of breast cancer cells. However in certain cases, breast cancer patients present with intrinsic resistance to tamoxifen treatment [3] and increasing the dose will only lead to the problem of undesirable effects to the patients as a result of the drug action on

\footnotetext{
* Correspondence: niksoriani@usm.my

Department of Chemical Pathology, School of Medical Sciences, Universiti Sains Malaysia, Health Campus, 16150 Kubang Kerian, Kelantan, Malaysia
}

normal tissues and cells. These include endometrial cancer risk [4], risk of liver cancers [5] and effect on eyesight [6]. Chromosomal aberrations and DNA damage have also been reported in several cell types and animal organs [7-9]. Tamoxifen undergoes metabolic reactions involving the cytochrome P450 enzyme family and lack of this enzyme family was suggested to lead to tamoxifen resistance of the cancer cells [10].

Honey is a natural product containing a complex mixture of sugars, minerals, proteins, vitamins, organic acids, flavonoids, phenolic acids, enzymes and other phytochemicals. It contains antioxidant molecules such as flavonoids, phenolic acids, catalase, carotenoids, peroxidase and catalase [11]. Honey's many potential health benefits have 
amounted great interest in its use as an alternative remedy for various ailments by the general public [12]. Research has shown that honey is capable of inhibiting the growth of bladder cancer cell lines and is effective against murine bladder cancer implantation [13]. More recently, a Nigerian jungle honey displayed antitumour activity in mice inoculated with Lewis Lung Carcinoma cells [14] and Manuka honey inhibited the proliferation of murine melanoma, colorectal carcinoma and breast cancer cells as well as tumour growth in a melanoma tumour model [15]. Tualang honey (TH) is a wild multifloral Malaysian honey produced by Apis dorsata (Asian giant bees) that build their hives high up in the Tualang tree (Koompassia excelsa). We have recently shown that $\mathrm{TH}$ could inhibit growth of breast cancer cells, MCF-7 and MDA-MB-231, by inducing apoptosis [16] and promoted the anticancer effects of tamoxifen on these cells [17]. However, TH was observed to be noncytotoxic to the noncancerous breast epithelial cells, MCF-10A [16]. The present study was therefore carried out to further understand the differential effects of TH on MCF-7 and MCF-10A cells and to determine its influence on the activity of the tamoxifen metabolite, 4-hydroxytamoxifen (OHT) in these cells.

\section{Methods}

\section{Cell culture and treatment}

MCF-10A cell line was purchased from the American Type Culture collection and maintained in complete growth medium consisting of 1:1 mixture of Dulbecco's modified Eagle's medium and Ham's F12 medium supplemented with $5 \%$ fetal bovine serum, $20 \mathrm{ng} / \mathrm{ml}$ epidermal growth factor, $10 \mu \mathrm{g} / \mathrm{ml}$ insulin, $500 \mathrm{ng} / \mathrm{ml}$ hydrocortisone and $1 \mathrm{unit} / \mathrm{ml}$ penicillin/streptomycin. TH was supplied by the Federal Agricultural Marketing Authority Malaysia. This type of honey is produced by Asian giant bees (Apis dorsata) that built their hives on Tualang trees (Koompassia excels) in the Malaysian jungle. Prior to cell treatment, the TH was freshly prepared by dissolving it in serum-free culture medium at a final concentration of $10 \%(\mathrm{v} / \mathrm{v})$ and then was filter-sterilized using $0.22 \mu \mathrm{m}$ syringe filter unit (Millipore, USA). The tamoxifen metabolite, OHT, was obtained from Sigma-Aldrich ${ }^{\circ}$, dissolved in ethanol and stored at $-20^{\circ} \mathrm{C}$ in aliquots. Cells were treated with OHT, $\mathrm{TH}$ or their combination for up to $72 \mathrm{hr}$.

\section{Cytotoxicity assay}

Cells were seeded in 24-well cell culture plates (Nunc, Denmark) at a density of $1 \times 10^{5}$ cells $/ \mathrm{ml}$ in a complete growth medium for $24 \mathrm{hr}$ at $37^{\circ} \mathrm{C}$ in a humidified incubator. The culture medium was replaced with assay medium ( $2 \%$ fetal bovine serum and without epidermal growth factor) prior to treatment with $\mathrm{TH}(1 \%)$, OHT (10 or $15 \mu \mathrm{M})$ or their combination for up to $72 \mathrm{hr}$. Culture cell supernatants $(100 \mu \mathrm{l})$ were transferred into a 96-well microplate and the cytotoxicity was assessed using Lactate Dehydrogenase (LDH) Cytotoxicity Detection Kit (Roche, Germany) according to the manufacturer's instructions.

\section{Proliferation assay}

Cells were seeded in a 96 well plate at a density of $2 \times 10^{4}$ cells per well and treated with $1 \% \mathrm{TH}, 10 \mu \mathrm{M}$ OHT, $15 \mu \mathrm{M}$ OHT and their combination for 24 and $48 \mathrm{hr}$. At the end of treatment, $20 \mu \mathrm{l}$ of MTT $(5 \mathrm{mg} / \mathrm{ml})$ was added to each well and the plate was incubated for $4 \mathrm{~h}$ at $37^{\circ} \mathrm{C}$ with $5 \% \mathrm{CO}_{2}$. The medium was then aspirated and $100 \mu \mathrm{l}$ of DMSO was added to each well to dissolve the tetrazolium crystals produced by viable cells. Absorbance was measured using a plate reader (VersaMax, Molecular Devices, US) at $540 \mathrm{~nm}$ wavelength.

\section{Comet assay}

Cells were seeded as above and treated with TH (1\%), OHT $(10 \mu \mathrm{M})$ and their combination of both for $24 \mathrm{hr}$. Cells were then collected by trypsinisation and washed with PBS. Comet assay analysis was performed by using Trevigen's Commet Assay ${ }^{\circ}$ kit (Trevigen, Inc) according to the manufacturer's instructions. Briefly, cell pellets were mixed with low melting point agarose at a ratio of 1:10 (v/v) and pipetted onto the CometSlide ${ }^{\mathrm{m}}$. Cells were then lysed in the lysis solution before been treated with alkali solution in order to unwind and denature the DNA and hydrolyze sites of damage. The samples were then electrophoresed, stained with a fluorescent DNA intercalating dye $\left(\mathrm{SYBR}^{\circ}\right.$ green 1$)$ and visualized under fluorescence microscope (Nikon, Tokyo, Japan) using a band pass FITC filter (excitation $490 \mathrm{~nm}$, emission $>520 \mathrm{~nm}$ ). Fifty cells were randomly selected and captured per sample using 100× magnification and were analyzed by using Comet Image Analysis System software (CometScores software; TriTek, Sumerduck, VA, USA) that is available at http://www.autocomet.com/products_cometscore.php. Tail length, \% of DNA in the tail and Olive moment were used as evaluation of the DNA damage.

\section{Western blotting}

Cells cultured in $75 \mathrm{~cm}^{2}$ flasks at a density of $1 \times 10^{6}$ cells/ $\mathrm{ml}$ were treated with $\mathrm{TH}(1 \%)$, OHT $(10 \mu \mathrm{M})$ or their combination for $24 \mathrm{hr}$. Cell were lysed in $150 \mu \mathrm{l}$ lysis buffer (50 mM of Tris- $\mathrm{HCl}, 150 \mathrm{mM}$ of $\mathrm{NaCl}, 0.2 \%$ SDS, $1 \mathrm{mM}$ PMSF, $2 \mu \mathrm{g} / \mathrm{ml}$ of leupeptin, $2 \mu \mathrm{g} / \mathrm{ml}$ of aprotinin and $1 \mathrm{mM}$ of $\mathrm{Na}_{3} \mathrm{VO}_{4}$ ) and the lysates were obtained by centrifugation at $12,000 \mathrm{rpm}$ for $2 \mathrm{~min}$ at $4^{\circ} \mathrm{C}$. The protein concentrations were determined using a spectrophotometer (NanoDrop) at $280 \mathrm{~nm}$ absorbance. For western blot analysis, $100 \mu \mathrm{g}$ of protein was resolved on 10\% SDSpolyacrylamide gel for $1 \mathrm{hr}$ followed by semi-dry transfer 
onto PVDF membrane and blocking using 5\% skimmed milk diluted in the TBS-Tween 20. Next, the membrane was washed with TBS-Tween20 and incubated with the primary antibody ( $\operatorname{Rad} 51, \mathrm{Ku} 70 / \mathrm{Ku} 80$ and $\beta$-actin; Abcam, USA) overnight at $4{ }^{\circ} \mathrm{C}$. After washing with TBSTween 20, the membrane was incubated with secondary antibody conjugated with horseradish peroxidase for $1 \mathrm{hr}$ at room temperature. Antibody binding was detected by incubating the membrane with $\mathrm{ECL}^{\mathrm{TM}}$ Prime Western Blotting reagent according to the manufacturer's protocols and visualized using an image analyzer under chemiluminescence filter. The band density for each treatment compared to control was analyzed using ImageJ 1.46 software (http://imagej.nih.gov/ij/) and the values were normalized to the $\beta$-actin band density.

\section{Statistical analysis}

Triplicates of three independent experiments were carried out and data are expressed as the mean \pm SD. Differences between the groups were evaluated by using Student Ttest or one-way analysis of variance (ANOVA) followed by post hoc Tukey multiple comparison test with the aid of GraphPad Prism 5 software. $\mathrm{p}<0.05$ was taken as being statistically significant.

\section{Results and discussion}

Various studies have recently been conducted to explore the medicinal benefits of Tualang honey and findings have shown that $\mathrm{TH}$ has significant anticancer activity against human cancer cell lines such as breast, cervical [16], oral and osteosarcoma [18]. Cancer cell death by TH occurs via induction of caspase-dependent apoptosis [16]. Recently, 7,12-dimethylbenz [a] anthracene (DMBA)-induced breast tumours in TH-treated rats were reported to be much less in number, volume and weight with better histological grade and morphology compared to the non-honey treated rats [19]. The anticancer activities showed by TH could be attributed to its antioxidant property as shown by the high total phenolic content and total antioxidant activity based on the ferric reducing ability of plasma (FRAP) assay [20]. Other than phenolic compounds, peptides, organic acids, enzymes and other minor components could also contribute to the antioxidant capacity of honey [11].

Tamoxifen is widely used as an antioestrogen for treatment of breast cancer [21] but several side effects have been noted including increased endometrial and colorectal cancer risk reviewed in [22] that could be attributed to the drug's ability to form DNA adducts through $\alpha$ hydroxylation of the parent molecule and its metabolites
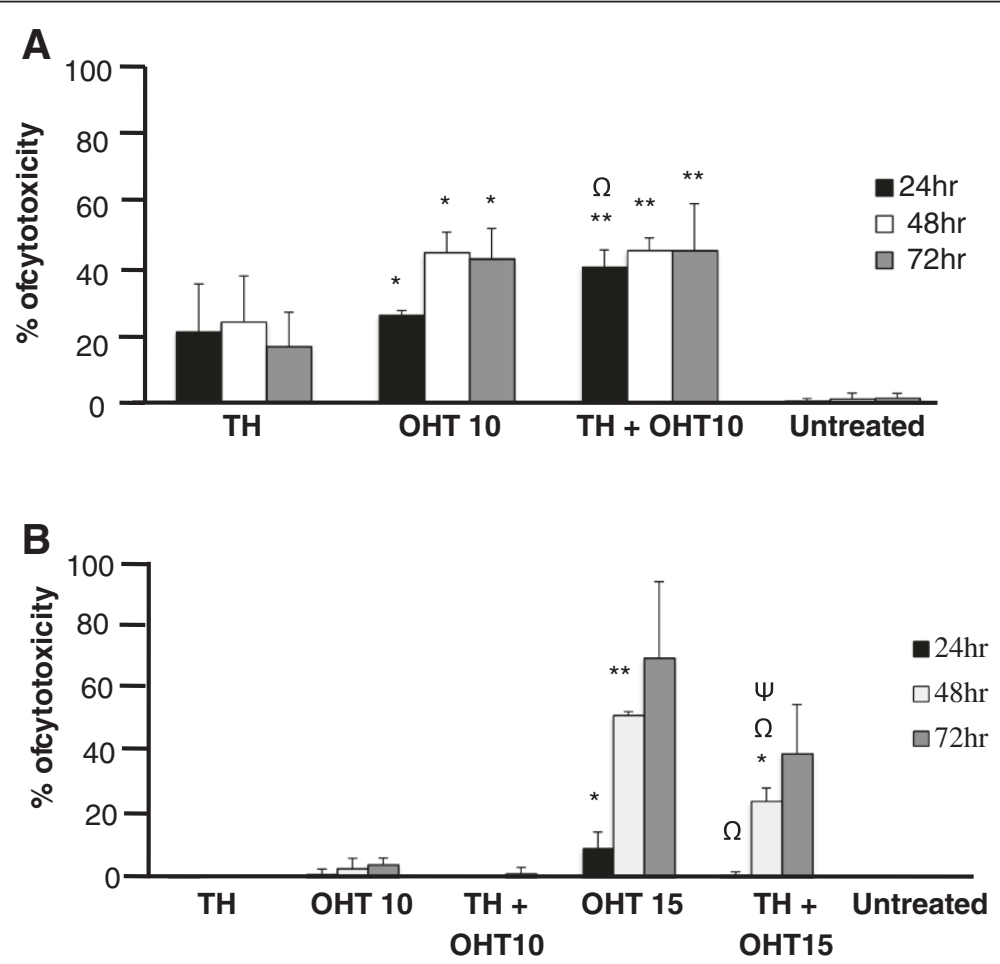

Figure 1 Cytotoxicity of TH and OHT on MCF-7 and MCF-10A cells. MCF-7 (A) and MCF-10A (B) cells were treated with OHT (10 and 15 HM), $\mathrm{TH}(1 \% \mathrm{v} / \mathrm{v})$ and their combination for up to $72 \mathrm{hr}$ and cell death was determined using LDH assay. Each value represents the mean \pm SD from three independent experiments. Statistical significance was determined by using the Student T test. ${ }^{\psi} \mathrm{p}<0.05$ for $\mathrm{TH}+\mathrm{OHT}$ compared to TH; $\Omega_{p}<0.01$ for $\mathrm{TH}+\mathrm{OHT}$ compared to OHT; ${ }^{*} p<0.05,{ }^{* *} p<0.01$ compared to untreated cells. 
including OHT $[23,24]$. The drawbacks of chemotherapeutic agents have led to the search and development of new antitumor candidates or adjuvants. However in many cases non-cancerous cells often are not tested alongside the cancerous cells. The idea that TH activities could possibility be selective against cancerous cells came from an initial study which showed that human breast carcinoma cell lines, MCF-7 and MDA-MB-231, were highly sensitive to $\mathrm{TH}$ while the non-cancerous MCF-10A breast epithelial cells were not affected [16]. The present study was therefore carried out to further understand the differential effects of TH on MCF-7 and MCF-10A cells and to determine its influence on the activity of OHT in these cells. The dose of honey selected was based on our previously published concentration that caused apoptosis as well as promotion of tamoxifen-induced apoptosis of MCF-7 cells [17]. The concentration of OHT chosen was within the ranges reported in the literature for breast cancer cells including MCF-7 $[25,26]$.

Both TH $(1 \%)$ and OHT $(10 \mu \mathrm{M})$ were found to be cytotoxic to MCF-7 cells with the latter being more effective with longer treatment duration (Figure 1A). In line with our previous findings of increased apoptosis with the combination of TH and tamoxifen [17], the current study also shows that TH promoted the cytotoxic effect of the tamoxifen derivative, OHT, in the cancerous MCF-7 cells from $25.2 \%$ to $38.9 \%$ within $24 \mathrm{hr}$. At $15 \mu \mathrm{M}$ concentration, OHT was also cytotoxic to the non-cancerous MCF$10 \mathrm{~A}$ cells and the effect increased with exposure time causing $70.1 \%$ cell death after $72 \mathrm{hr}$ (Figure 1B). This is in agreement with the report of Petinari et al. [27] where tamoxifen was found to be cytotoxic to both cancerous and non-cancerous cell lines at micromolar concentrations and was in fact reported to be more aggressive in the noncancerous cells. This was thought to be due to the higher expression of estrogen receptor by these non-cancerous cells. Interestingly, rather than promoting OHT's activity as observed with the MCF-7 cells, TH significantly ameliorated the cytotoxic effect of the antioestrogen in MCF-10A cells at all time points (Figure 1B) suggesting TH's protective effect in non-cancerous cells. The cytotoxicity results observed are supported by the findings of the MTT assay (Figure 2). TH was found to markedly increase the proliferation of MCF10A cells while not significantly affecting the proliferation of MCF-7 cells. OHT on the other hand, reduced the proliferation of MCF-10A cells but the presence of TH partially abrogated this inhibition. Proliferation of MCF-7 cells was not significantly modulated by all treatments. Tamoxifen induces chromosomal breaks [7] and is genotoxic to both normal lymphocytes and breast cancer cells [9]. Formation of DNA single- and doublestrand breaks and oxidative modifications of purines

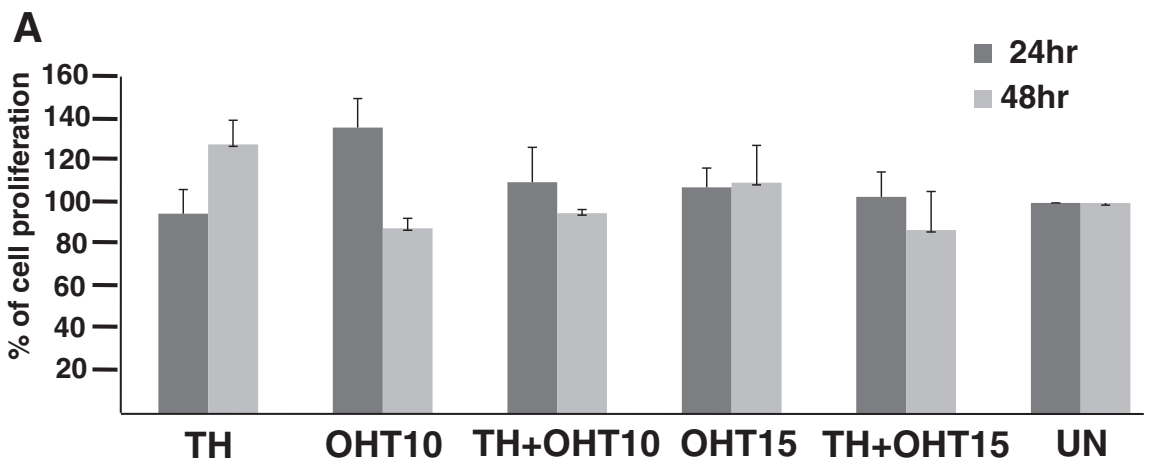

B

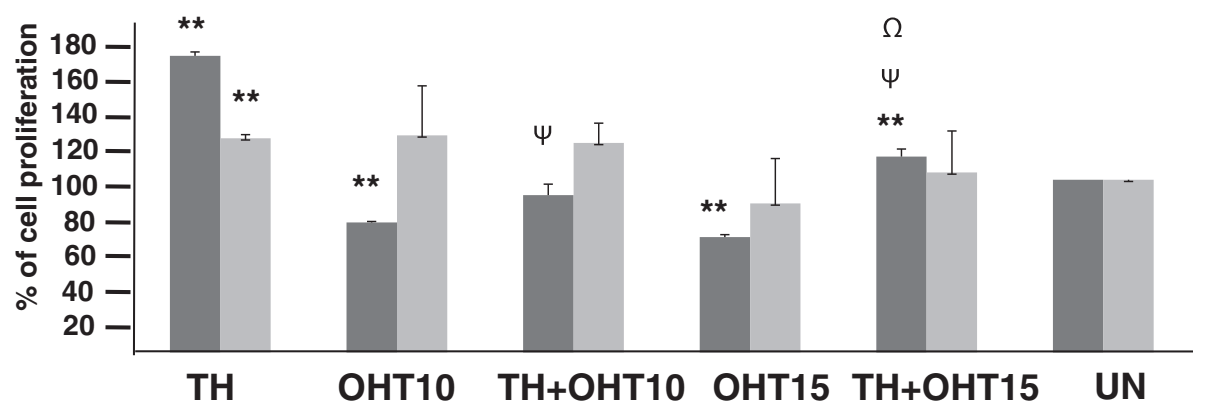

Figure 2 Proliferation of MCF-7 and MCF-10A cells induced by TH and OHT. MCF-7 (A) and MCF-10A (B) cells were treated with OHT $(10$ and $15 \mu \mathrm{M}), \mathrm{TH}(1 \%)$ and their combination for up to $48 \mathrm{hr}$ followed by an MTT assay. Each value represents the mean \pm SD that has been normalized against the respective control (taken as 100\%). Statistical significance was determined by using the Student T test. ${ }^{\psi} \mathrm{p}<0.01$ for TH + OHT compared to $\mathrm{TH}_{;}{ }^{\psi} \mathrm{p}<0.01$ for $\mathrm{TH}+\mathrm{OHT}$ compared to $\mathrm{OHT} ;{ }^{*} \mathrm{p}<0.05$, ${ }^{* *} \mathrm{p}<0.01$ compared to untreated cells. 
and pyrimidines in these cells were thought to involve free radical generation [9].

In the current study, comet assay was performed to evaluate total cellular DNA damage. A suboptimal concentration $(10 \mu \mathrm{M})$ of OHT was used for the comet assay so that at least the required $90 \%$ living cells were present to avoid false positive results (according to the manufacturer's recommendations). Assessment of percentage of DNA in the comet tail, the tail length and Olive moment show that OHT induced significant DNA damage in MCF-7 cells (Figure 3) as well as MCF-10A cells (Figure 4), indicating that accumulation of DNA damage is involved in OHTinduced cytotoxicity in both cancerous and non-cancerous cell lines. OHT was found to be more genotoxic to MCF10A than MCF-7 cells with DNA content in the tail of
$27.2 \%$ and $15.8 \%$, respectively. MCF-10A cells also displayed higher values of tail length and Olive moment. On the other hand, TH induced DNA damage only in MCF-7 cells and did not affect the integrity of DNA in MCF-10A cells.

We then show that the combination of $\mathrm{OHT}$ and $\mathrm{TH}$ promoted more extensive DNA damage in the cancerous MCF-7 cells as reflected by the significantly higher percentage of DNA in the tail of the comet (increased from 15.8 to $26.1 \%$ ), as well as the increased tail length and olive moment compared to OHT treatment alone (Figure 3). In contrast, $\mathrm{TH}$ significantly reduced the DNA damage induced by OHT (reduced from 27.2 to $9.6 \%$ ) in MCF-10A cells (Figure 4). Wozniak et al. [9] reported that DNA strand breaks induced by tamoxifen were more persistent

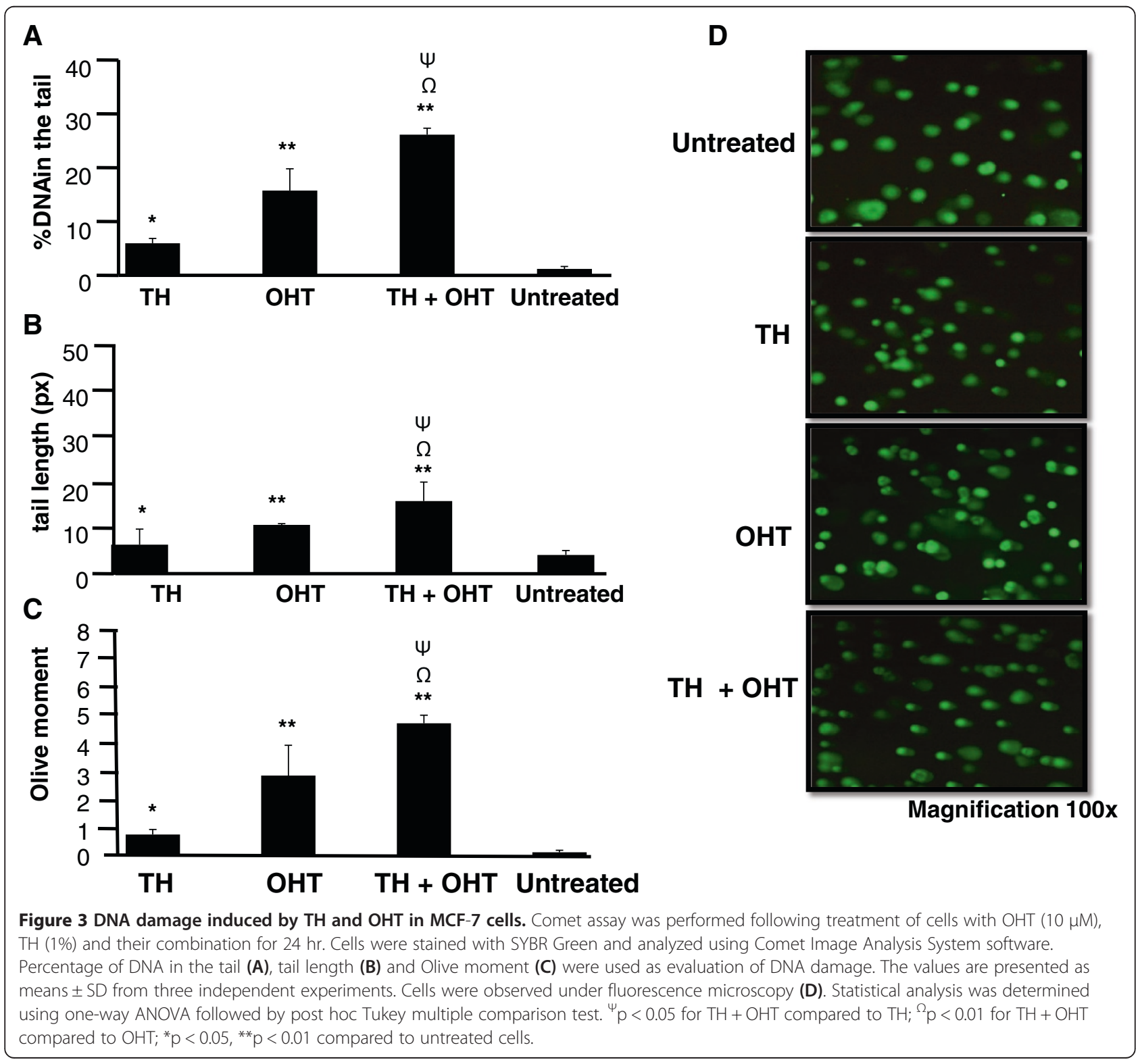




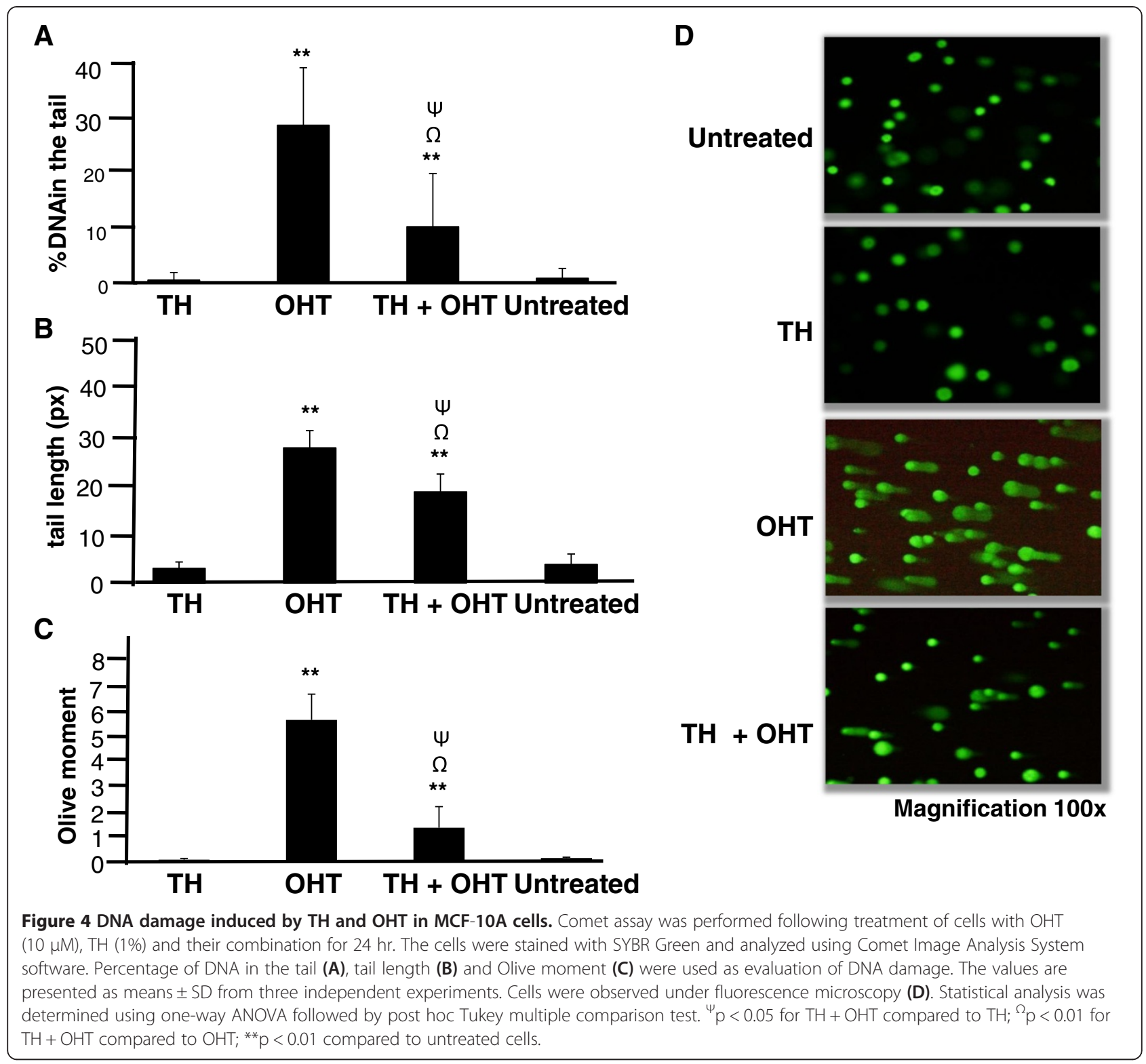

in normal cells compared to cancerous cells probably because of less effective repair mechanisms. Long-term exposure to this drug may therefore induce mutations in critical genes especially those involved in the DNA repair pathways. Repair of DNA lesions is therefore critical for the cell to preserve the integrity of its genomic and incomplete repair could later lead to malignant transformation $[28,29]$. According to Ellsworth et al. [30], genetic abnormalities have been observed in histologically normal epithelial cells surrounding breast carcinomas and that abnormalities of tumourigenic importance could accumulate in these cells. It could therefore be inferred from the current findings that $\mathrm{TH}$ may have the ability to repair and/or preserve genomic stability in the normal cells.
We further examined whether differences in DNA damage effects in the cancerous and non-cancerous cells induced by $\mathrm{TH}$ is associated with modulation of the expression of Rad51, Ku70 and Ku80 enzymes which are involved in the repair of DNA double strand breaks. Rad51 plays a role in the strand break repair through homologous recombination while Ku70 and Ku80 are involved in nonhomologous end joining repair pathway without the requirement for a homologous template [31]. Although they both form a heterodimer, it is possible that they function independently [32]. Inability to repair DNA damage could lead to genetic instability or mutation or chromosomal aberration that could enhance cancer development [31]. Analysis of more than 100 tumour specimens revealed that 


MCF-7
Figure 5 Expression of DNA repair enzymes in MCF-7 and MCF-10A cells treated with TH and OHT. The expression of Rad51, Ku70 and
Ku80 in the cells was determined by Western blotting following 24 hr exposure to OHT (10 $\mu$ M), TH (1\%) Or their combination. The protein bands
were visualized using an image analyzer and band density was analysed using ImageJ software with fold-change difference of expression
compared to untreated cells (UT) written below each band.

Rad51 over expression significantly correlates with mammary tumour grading and is considered as a potential biomarker for diagnosis and prognosis of invasive ductal mammary carcinoma [33]. In a study conducted by Pucci et al. [34], Ku70 and Ku80 heterodimer binding activity and the heterodimer DNA repair capability were reduced in advanced breast and bladder tumours [34].

Our results show that Rad51 protein was not upregulated by either $\mathrm{OHT}$ or $\mathrm{TH}$ alone or their combination indicating a non-significant role of this repair enzyme. In contrast, both OHT and TH increased Ku70 (2.40- and 2.67-fold, respectively) and Ku80 (1.89- and 1.69-fold, respectively) expression in MCF-7 cells. However in MCF$10 \mathrm{~A}$ cells, a marked overexpression of $\mathrm{Ku} 70$ (3.32-fold) and Ku80 (2.35-fold) was observed following TH treatment but not by OHT (Figure 5). The presence of TH together with $\mathrm{OHT}$ in MCF-10A cells upregulated the expression of $\mathrm{Ku} 70$ but not Ku80 in comparison with OHT treatment alone. The results suggest for the ability of $\mathrm{TH}$ to enhance the capability of DNA double strand DNA repair through the non-homologous end-joining repair pathway, especially in the non-cancerous breast epithelial cells. We saw earlier that TH dampened the DNA damage induced by OHT in the noncancerous cells and this is corroborated by the overexpression of Ku70 DNA repair enzyme in cells treated with both $\mathrm{TH}$ and OHT compared to OHT treatment alone. There are other proteins involved in double strand DNA repair and it is currently not known whether their expression would also be modulated by $\mathrm{TH}$. Our findings further suggest that $\mathrm{TH}$ is able to protect the DNA integrity against the tamoxifen metabolite, OHT, in non-cancerous cells and thereby preventing initiation of a chain of reactions that transform these into cancer cells. This differs from the action of the phytoestrogen, genistein, which acts as an antioxidant that protected both normal and cancer cells against the genotoxic potential of tamoxifen [9]. Similarly, TH was shown to protect keratinocytes from DNA damage induced by ultraviolet radiation and the reduced pyrimidine dimer formation could be the result of enhanced repair [35]. Tamoxifen is capable of generating ROS in vitro [36] that would mediate the OHT-induced DNA damage observed. The protective effect of TH against this DNA damage in the non-cancerous cells could therefore be due to the ability of antioxidant compounds present in the honey to quench the ROS generated. This is supported by the study of Beretta et al. [37] that showed honey antioxidants protected cells against free radical scavenging action and boost intracellular GSH generation.

\section{Conclusions}

The current study shows that TH enhances OHT-induced cytotoxicity and DNA damage in breast cancer cells while affording protection to the non-cancerous cells. This involves upregulation of double strand DNA repair enzymes that may thus increase the efficiency of DNA repair mechanism in these cells, and thereby preserving the cellular DNA integrity. The potential of TH to arrest breast cancer growth while protecting normal breast epithelium should be further explored in vivo. At least the use of $\mathrm{TH}$ may be able to reduce the toxic effects of a chemotherapeutic agent that could improve the quality of life for breast cancer patients.

\section{Abbreviations \\ TH: Tualang honey; OHT: 4-hydroxytamoxifen; ER: Estrogen receptor. \\ Competing interests \\ The authors declare that they have no competing interests.}

\section{Authors' contributions}

NF Ismail carried out the laboratory work, analysed the data and was involved in drafting the manuscript. NS Yaacob conceived and designed the study, interpreted the data and prepared the manuscript. Both authors read and approved the final manuscript. 


\section{Acknowledgements}

This study was partly supported by USM Research University Grants (1001.PPSP.853002 and 1001.PPSP.8120207). NF Ismail was sponsored by the Yayasan Bank Rakyat, Malaysia.

Received: 8 December 2013 Accepted: 12 March 2014 Published: 19 March 2014

\section{References}

1. Jiang Q, Zhong Q, Zhang Q, Zheng S, Wang G: Boron-based 4-Hydroxytamoxifen bioisosteres for treatment of de Novo Tamoxifen resistant breast cancer. ACS Med Chem Lett 2012, 3:392-396.

2. Harvey JM, Clark GM, Osborne CK, Allred DC: Estrogen receptor status by immunohistochemistry is superior to the ligand-binding assay for predicting response to adjuvant endocrine therapy in breast cancer. J Clin Oncol 1999, 17:1474-1484.

3. Musgrove EA, Sutherland RL: Biological determinants of endocrine resistance in breast cancer. Nat Rev Cancer 2009, 9:631-643.

4. Early Breast Cancer Trialists' Collaborative Group: Tamoxifen for early breast cancer: an overview of the randomized trials. Lancet 1998, 351:1451-1467.

5. White I: Tamoxifen: is it safe? Comparison of activation and detoxication mechanisms in rodents and in humans. Curr Drug Metab 2003, 4:223-239.

6. Omoti AE, Omoti CE: Ocular toxicity of systemic anticancer chemotherapy. Pharm Pract 2006, 4:55-59.

7. Mizutani A, Okada T, Shibutani S, Sonoda E, Helfrid H, Nishigori C, Miyachi YB, Takeda SA, Yamazoe MA: Extensive chromosomal breaks are induced by tamoxifen and estrogen in DNA repair-deficient cells. Cancer Res 2004, 64:3144-3147.

8. Carthew P, Lee PN, Edwards RE, Heydon RT, Nolan BM, Martin EA: Cumulative exposure to tamoxifen: DNA adducts and liver cancer in the rat. Arch Toxicol 2001, 75:375-380.

9. Wozniak K, Kolacinska A, Blasinska-Morawiec M, Morawiec-Bajda A, Morawiec Z, Zadrozny M, Blasiak J: The DNA-damaging potential of tamoxifen in breast cancer and normal cells. Arch Toxicol 2007, 81:519-527.

10. Hoskins JM, Carey LA, McLeod HL: CYP2D6 and tamoxifen: DNA matters in breast cancer. Nat Rev Cancer 2009, 9:576-586.

11. Gheldof N, Engeseth NJ: Antioxidant capacity of honeys from various floral sources based on the determination of oxygen radical absorbance capacity and inhibition of in vivo lipoprotein oxidation in human serum samples. J Agric Food Chem 2002, 50:3050-3055.

12. Manyi-Loh CE, Clarke AM, Ndip RN: An overview of honey: Therapeutic properties and contribution in nutrition and human health. Afr $\mathrm{J}$ Microbiol Res 2011, 5:844-852.

13. Swellam T, Miyanaga N, Onozawa M, Hattori K, Kwai K, Shimazui T, Akaza H: Antineoplastic activity of honey in an experimental bladder cancer implantation model: in vivo and in vitro studies. Int J Urol 2003, 10:213-219.

14. Fukuda M, Kobayashi K, Hirono Y, Miyagawa M, Ishida T, Ejiogu EC, Sawai M, Pinkerton KE, Takeuchi M: Jungle honey enhances immune function and antitumor activity. Evid Based Complement Altern Med 2011, 2011:8.

15. Fernandez-Cabezudo MJ, El-Kharrag R, Torab F, Bashir G, George JA, El-Taji H, Al-Ramadi BK: Intravenous administration of manuka honey inhibits tumor growth and improves host survival when used in combination with chemotherapy in a melanoma mouse model. PLoS One 2013, 8:e55993.

16. Fauzi AN, Norazmi MN, Yaacob NS: Tualang honey induces apoptosis and disrupts the mitochondrial membrane potential of human breast and cervical cancer cell lines. Food Chem Toxicol 2011, 49:871-878.

17. Yaacob NS, Fauzi AN, Norazmi MN: Tualang honey promotes apoptotic cell death induced by tamoxifen in human breast cancer cell lines. Evid Based Complement Altern Med 2013, 2013:989841.

18. Ghashm AA, Othman NH, Khattak MN, Ismail NM, Saini R: Antiproliferative effect of Tualang honey on oral squamous cell carcinoma and osteosarcoma cell lines. BMC Complement Altern Med 2010, 10:1-8.

19. Kadir EA, Sulaiman SA, Yahya NK, Othman NH: Inhibitory effects of Tualang Honey on experimental breast cancer in rats: a preliminary study. Asian Pac J Cancer Prev 2013, 14:2249-2254.

20. Mohamed M, Sirajudeen KNS, Swamy M, Yaacob NS, Sulaiman SA: Studies on the antioxidant properties of Tualang honey of Malaysia. Afr J Tradit Complement Altern Med 2010, 7:59-63.

21. Bush NJ: Advances in hormonal therapy for breast cancer. Semin Oncol Nurs 2007, 23:46-54.
22. Brown K: Is tamoxifen a genotoxic carcinogen in women? Mutagenesis 2009, 24:391-404.

23. McLuckie KIE, Routledge MN, Brown K, Gaskell M, Farmer PB, Roberts GCK, Martin EA: DNA adducts formed from 4-hydroxytamoxifen are more mutagenic than those formed by a-acetoxytamoxifen in a shuttle vector target gene replicated in human Ad293 cells. Biochemistry 2002, 41:8899-8906.

24. Kim SY, Suzuki N, Laxmi YR, Shibutani S: Genotoxic mechanism of tamoxifen in developing endometrial cancer. Drug Metab Rev 2004, 36:199-218.

25. Bollig A, Xu L, Thakur A, Wu J, Kuo TH, Liao JD: Regulation of intracellular calcium release and PP1alpha in a mechanism for 4-hydroxytamoxifeninduced cytotoxicity. Mol Cell Biochem 2007, 305:45-54.

26. Duan L, Motchoulski N, Danzer B, Davidovich I, Shariat-Madar Z, Levenson W Prolylcarboxypeptidase regulates proliferation, autophagy, and resistance to 4-hydroxytamoxifen-induced cytotoxicity in estrogen receptor-positive breast cancer cells. J Biol Chem 2011, 286:2864-2876.

27. Petinari L, Kohn LK, Carvalho JE, Genari SC: Cytotoxicity of tamoxifen in normal and tumoral cell lines and its ability to induce cellular transformation in vitro. Cell Biol Int 2004, 28:531-539.

28. Liang Y, Lin S-Y, Brunicardi FC, Goss J, Li K: DNA damage response pathways in tumor suppression and cancer treatment. World J Surg 2009, 33:661-666.

29. Thomas CG, Strom A, Lindberg K, Gustafsson JA: Estrogen receptor beta decreases survival of p53-defective cancer cells after DNA damage by impairing G2/M checkpoint signaling. Breast Cancer Res Treat 2011, 127:417-427.

30. Ellsworth DL, Ellsworth RE, Liebman MN, Hooke JA, Shriver CD: Genomic instability in histologically normal breast tissues: implications for carcinogenesis. Lancet Oncol 2004, 5:753-758.

31. Khanna KK, Jackson SP: DNA double-strand breaks: signaling, repair and the cancer connection. Nat Genet 2001, 27:247-254.

32. Li H, Vogel H, Holcomb VB, Gu Y, Hasty P: Deletion of Ku70, Ku80, or both causes early aging without substantially increased cancer. Mol Cell Biol 2007, 27:8205-8214.

33. Maacke H, Opitz S, Jost K, Hamdorf W, Henning W, Krüger S, Feller AC Lopens A, Diedrich K, Schwinger E, Stürzbecher HW: Over-expression of wild-type Rad51 correlates with histological grading of invasive ductal breast cancer. Int J Cancer 2000, 88:907-913.

34. Pucci S, Mazzarelli P, Rabitti C, Giai M, Gallucci M, Flammia G, Alcini A, Altomare V, Fazio VM: Tumor specific modulation of KU70/80 DNA binding activity in breast and bladder human tumor biopsies. Oncogene 2001, 20:739-747.

35. Ahmad I, Jimenez H, Yaacob NS, Yusuf N: Tualang Honey protects keratinocytes from ultraviolet radiation-induced inflammation and DNA damage. Photochem Photobiol 2012, 88:1198-1204.

36. Lee YS, Kang YS, Lee SH, Kim JA: Role of NAD(P)H oxidase in the tamoxifen-induced generation of reactive oxygen species and apoptosis in HepG2 human hepatoblastoma cells. Cell Death Differ 2000, 7:925-932

37. Beretta G, Orioli M, Maffei Facino R: Antioxidant and radical scavenging activity of honey in endothelial cell cultures (EA.hy926). Planta Med 2007, 73:1182-1189.

\section{doi:10.1186/1472-6882-14-106}

Cite this article as: Yaacob and Ismail: Comparison of cytotoxicity and genotoxicity of 4-hydroxytamoxifen in combination with Tualang honey in MCF-7 and MCF-10A cells. BMC Complementary and Alternative Medicine 2014 14:106

\section{Submit your next manuscript to BioMed Central and take full advantage of:}

- Convenient online submission

- Thorough peer review

- No space constraints or color figure charges

- Immediate publication on acceptance

- Inclusion in PubMed, CAS, Scopus and Google Scholar

- Research which is freely available for redistribution 